\title{
THE STUDY ON THE FUNCTIONAL ASPECTS OF MOSQUE INSTITUTION
}

Received Feb. 25, 2021 | Accepted Sept. 28, 2021 | Available online Dec. 15, 2021 |

DOI http://dx.doi.org/10.18860/iia.v6i4.11749 |

\section{Nayeem Asif}

Kulliyyah of Architecture and Environmental Design International Islamic University Malaysia

Gombak, Malaysia

nayeem@iium.edu.my

\section{Nangkula Utaberta}

Department of Architecture, Faculty of Civil Engineering and Architecture,

Univesiti Tun Hussein Onn Malaysia

Johor, Malaysia

nangkulautaberta@gmail.com

\section{Sumarni Ismail \\ Faculty of Design and Architecture, \\ Universiti Putra Malaysia \\ Serdang, Malaysia \\ sumarni.upm@gmail.com}

\section{Muhammad Ihsan Shaharil}

Kulliyyah of Architecture and Environmental Design, International Islamic University Malaysia

Gombak, Malaysia

muhammadihsan@iium.edu.my

\begin{abstract}
It was the norm for Muslim armies during the early period that whenever a new territory was conquered, the first establishment would be a mosque. That mosque served simultaneously as the military base, administrative office, and place for congregational prayers. However, at present, the function of the mosque institution has become more diversified and flexible. This paper aims to study the historical precedence of a mosque's function and the current perception of the mosque programs. The paper adopts the qualitative method through reviewing existing literature and analyzing the data using descriptive analysis. Recommendations are made based on the findings that show that the diversification of mosque's functions. It is highly needed in the present time as the Muslim community is facing rapid sociocultural changes. Moreover, the inclusiveness of mosque institutions is significant to ensure the participation from all strata of community. Further research on these aspects can be done to study specific mosques in selected contexts.
\end{abstract}

\section{KEYWORDS:}

Inclusive mosque; Communal-mosque; Prophetic tradition; Mosque management; Community development; Functional flexibility.

\section{INTRODUCTION}

Islam started with philosophy and doctrine that encouraged the solidarity and integration of people to form one community. According to the Islamic principles, Muslims must gather at one common place five times a day and several times occasionally within a year [1].

The concept of the mosque, both as a place for communal gathering and prostration, evolved in Islam is not only out of the needs for religious rituals but also for the community's social necessities [1].

Taking the value of the mosque of Prophet (PBUH), it should be noted that Prophet's (PBUH) mosque was the center of the wide range of the fast emerging Muslim activities and aspirations community. The mosque's impact was so significant in the lives of the Muslim community of Madinah that the city eventually grew in a ring shape centering on the mosque complex [2]. It clearly shows how the mosque and the community were interconnected so that the day-to-day activities, which were mostly secular, were centered on none other institution than the mosque.

The objective of this paper is to assess the current crisis of the inactiveness of mosque institutions and highlight the potential of mosques to actively contribute to community development through diversified programs. Therefore, this paper aims to assess the function of a mosque from a historical and contemporary perspective by studying the works of prominent scholars in this field and recommending the potential programs for mosque institutions in the $21^{\text {st }}$ century.

\section{ACTIVITIES CONCERNING MOSQUE FROM HISTORICAL PRECEDENCE}

As stated by Desai, "from the humble beginning at Medina, through development at Kufa, Fustat, and Jerusalem up to the completed form of the congregational mosque built at Damascus, ninety years later, it took about three generations to evolve a unified and balanced architectural expression of the Islamic needs" [3]. In the early years of Islamic civilization, mosque institutions catered to people as the place where the Muslim nation could practice the balance between fulfilling its responsibility towards the Creator and its responsibility towards fellow human beings. In other words, they practiced the divine command of habluminallah wa. Habluminannas [4].

Then in later years, many other community functions started to evolve in and around the mosque. of these, the facilities for education, health, and 
shopping were important. Hamid, reported from Grabar, affirms that the later part of the eleventh century was marked with the appearance of Maktab, Madrasa, and so on. During the early Islamic period, Muslim generals, after conquering or establishing a city, used to establish a mosque at the city's central location, which served the purpose of socio-political control and religious activities. In addition, these are the mosques where a diversified range of facilities like Madrasa, Dormitory, Library, Shops, etc., were available [1]. Diagrammatic representations of a mosque complex with its various associated functions are presented in (Figure 1) as proposed by Hamid.

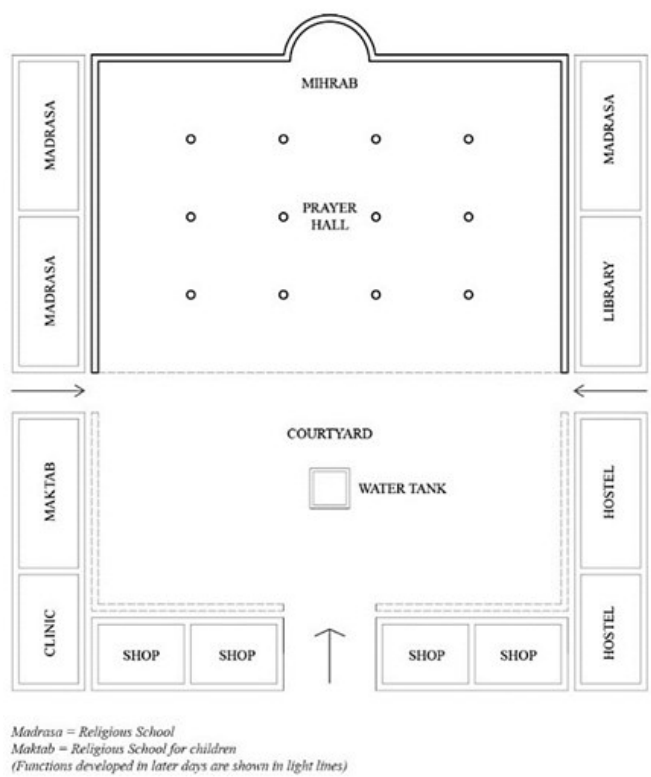

Figure 1. Diagrammatic representation of a mosque complex with its various associated functions [reproduced by the author according to [1]

The Prophet's (PBUH) mosque represents a model par excellence of the Islamic way of life [5] Performing call to prayers and congregational prayers at the formally appointed time is the major functions of a mosque, but also, there were other social, political, and administrative functions that should be noticed [6]. Tajuddin Rasdi marked out several characteristics, which he suggested, outlining the eternal idea of a mosque. According to his opinion, a mosque is a place for worship. Still, the sacred area for offering prayers should be limited so that the rest of the spaces can accommodate other flexible functions. Secondly, a mosque is a house of community, and in its very nature, it is a multifunctional building fulfilling the functions of administration, education, prayer, welfare, social activities, and judiciaries. Then, comes the functions related to social issues which act as a platform for fostering Islamic brotherhood. The final function of a mosque is concerned with its relation to the non-Muslim communities or the non-Muslim members of a Muslim dominated community. It is the Muslim community's responsibility to present the teachings and values of Islam to their fellow non-
Muslim communities [5].

The encyclopedia of Islam outlines a comprehensive functional character of the mosque institution. It states that the mosque in Madinah during the time of the Prophet (PBUH) was the effective seat of the government as well as the center of civil and military administration for the newly formed Muslim community [7].

In his book, titled 'Islamic Architecture: form, function and meaning', Robert Hillenbrand compiled a range of activities associated with the mosque institution from the Prophet (PBUH) era towards the later period of Islamic reign. This compilation illustrates a range of diversified religious and secular activities, establishing the fact that the mosque was always the center of activities within the communities rather than only being a place for worship. These activities consist of worship or spiritual activities, learning center, center for scholarship, publication and authorization (certification), library and book shops, accommodation for travelers with food facilities (i.e., kitchen), hospitals and morgues, lecture sessions, debate and discussions on daily issues in an academic manner, charity distribution, marriage, divorce, burial and so on. The mosque also served as a place to preserve relics, much like the modern-day museums, law courts, and military bases in newly conquered territories [8].

\section{INCLUSIVENESS OF THE MOSQUE'S PROGRAM}

A mosque must serve a varied range of functions, as briefly compiled by Tajuddin Rasdi in two major spectrums. He argued that the present-day mosques should have a curriculum of activities that generate the proper architectural guidelines for designing mosques. The two major spectrums are,

1) Intellectual development,

2) Strengthening the brotherhood of Islam.

These two spectrums contain the compulsory functions that should be incorporated in the mosque [9].

Another important issue regarding the compilation of the mosque's activities is to incorporate a friendly and welcoming atmosphere for all genders and age groups. Hesham emphasized that mosques should be designed in a child-friendly way, and he brought evidence from the life of the Prophet (PBUH). He said Prophet (PBUH) used to incorporate children in the mosque with a loving attitude and a welcoming atmosphere [10].

According to the opinion of Hamid (1973), children, apart from receiving religious education, can even play inside the mosque. As Imam Ghazzali wrote, "For children, there is no harm if they enter the mosque, and it is not unlawful for them to play inside the mosque. To remain silent at this scene is not unlawful, provided that the mosque is not turned into a playground" [1].

The same welcoming environment should also be maintained for the women. As Spahic Omer said, the first generation of Muslims capitalized on every opportunity to acquire and disseminate knowledge. Some of them were so devoted to it that they were 
ready to sacrifice some things they cherished. That's why the Prophet's (PBUH) mosque was always bustling with life. Study circles, intellectual discourses, meditation, etc., made the mosque virtually never devoid of people. Neither women nor children have been disregarded in this process. Even the Prophet (PBUH) designated some times of the week exclusively to teach the women and listen to their own issues in a very comfortable manner secured from the intrusion of men [6].

The statement illustrates the importance of incorporating women in the mosque and children to achieve the holistic purpose to be a center of community development.

As stated by Ismail et al., children will be the future generations in the society who will determine the nature of life and society of the future. In relation to this, society has to change its view concerning children, from the concept as those who do not understand anything to human beings who should be given the essential attention and provided with the exposure to religion, especially the function of mosques, at the earliest opportunity [11].

Careful and well-organized planning in the use of space must be emphasized in building mosques, particularly in relation to the separation of areas for men and women in all activities, encompassing the time for praying, taking ablution, and using the restrooms. Moreover, special spaces should be given to women with a special design for their needs, especially for the disabled with small children. Similarly, another special space should accommodate the need for women for taking ablution, which should be placed together with the special prayer space to facilitate their movements and activities when they are not putting on their hijab [11].

However, unfortunately, the present situation is different than the ideal one. It is shown by the report given by Svetlana Peshkova who conducted an interview with an Uzbek woman. The interviewee said, "We have a desire to go to the mosques, but in Uzbekistan, only men go there. We [women] are not very upset because the Quran says that one needs to read within a group, and we just do that at our meetings" [12]. Similar situations have been reported regarding other countries where women are not allowed to enter the mosque or participate in the activities therein [13].

Provision for people with disabilities is also crucial in planning mosques. Othman et al. stated that those who are disabled also have a right to participate in making the mosque's activities successful and effective with all the facilities for them being made, helped by the public [11]. The application of universal design in this built environment of the mosque is crucial to cater to a wider range of users. The significance of the application of universal design is an exigency in the mosque design process [14]. There is a tradition of the Prophet which narrates that those who are disabled also are not excluded from performing the prayers in congregation in mosques as long as such persons can listen to the call to prayer in the house, as stated in the Prophetic hadith:

It is narrated by Abu Hurayrah (Ra): A blind man came to the Messenger of Allah -peace, and blessings be upon him- asking "O Messenger of Allah, I do not have someone to direct and aid me to go the mosque." The man requested the Messenger -peace and blessings be upon him- to permit him to pray in his house. He obtained it. After he had gone home, the person was called back, and he was asked: "Can you listen to the call to prayer (adhan)?" The man answered, "Yes." The Messenger then said, "You should respond to the call (so you should go to the mosque"). [Sahih Muslim, Book no: 9, Hadith no: 1066, [15]

\section{METHODS}

This study will focus on the institution of the mosque from a functional perspective. Thus, the scope of this research will be confined within the boundary of analyzing the activity patterns and spatial provisions for those activities within the institution of the mosque. Furthermore, as the research will focus on the functional aspects of the mosque by analyzing the historical precedence and contemporary practices, the qualitative research method is chosen to conduct the process because it will allow collecting and compiling necessary data to conclude.

Analyzing literature or secondary analysis means that the researcher analyzes the data that were not collected for that particular study of that researcher. Rather, they are existing datasets that were produced for other purposes. Therefore, the literature survey will cover a wide range of time periods starting from the early texts of Islam until the recent academic and professional works. It will ensure a holistic background to analyze the data and organize the findings into appropriate sections and sub-sections focusing on the functional aspects of the mosque institution.

\section{FUNCTIONAL REQUIREMENTS OF MOSQUE IN CONTEMPORARY MUSLIM SOCIETIES}

Although historical evidence gave a broad spectrum of activities incorporated with the mosque and played a vital role in community development, reinterpretation of these functions in the modern context to address the issues of contemporary Muslim societies is required. Tajuddin Rasdi reported the statements delivered by many academics commenting on this matter. Like what has been mentioned by Ismail Kamus, who suggested that the Prophet's (PBUH) mosque was built solely to unite the Muslims in a single brotherhood, today's mosques should also be built to serve the same purpose [5].

This view was further strengthened by Suhaib Hasan and Akmal Haji M. Zain. One of them highlighted the importance of five daily prayers in the mosque, which should act as the mechanism for fostering brotherhood among Muslims. In contrast, others suggested using the mosque as a base for establishing 
a Muslim government through the unity of Muslim brotherhood. Dusuki Ahmad also emphasized this view [5].

Taib Azamuddin Mohamed Taib gave some important notions on the mosque from which Tajuddin Rasdi derived some guidelines for the mosque's architecture. According to Taib, mosques should be equipped with recreational facilities for children and adults. Accommodation for travelers, rentable rooms for Muslims, health clinics, public welfare offices, and space to sell certain products and items are the facilities that should be taken into account. [5]

Considering all these opinions, Tajuddin Rasdi proposed a theoretical framework of guidelines for the mosque architecture. These guidelines are aimed to address the issue of modern Muslim societies by considering their requirements, and the final programs are categorized under five distinct sections;

1. Educational program,

2. Social program,

3. Economic program,

4. Welfare program and

5. Judicial program [5]

Furthermore, Tamuri, Ismail, \& Jasmi state a need to develop a teaching and learning module of Islamic Education based on the mosque. His study assesses the effectiveness of the generated module by a quasi-experiment design. He derived that mosque has the potential to ensure a better quality of Islamic education within Muslim societies [16].

Hamad et al. assert that mosque had contributed a lot to developing Islamic education in Nigeria before independence. They implemented it in the first mosque of the Prophet Muhammad in the Qubah to serve as the fundamental one of all mosques on the earth. The study aims at examining the meaning of Islamic education, looks into the concepts of education in the Quran, looks into the aim and objective of Islamic education in human life, discusses the qualities of Islamic teachers, and mentions the role or impact of Muslim teachers in the Islamic education and society [17].

More contemporary research on the effectiveness of mosques during the time when disaster happened shows the universality of this community-based institution. That particular research focused on the functional aspect of a mosque in the earthquake-affected areas of Pakistan. It emphasized the suitability of community-based religious organizations in disaster management [18].

Candland reported that, during disasters, religious institutions contribute to the disaster mitigation drive in several ways, such as feeding hungry victims, providing shelter, and supporting communities in some ways. Religious institutions have played an important role in developing social cohesion and building social and safety networks within communities. Important to note that the activities stated here, such as feeding and providing shelter to the needy and supporting people of the community, are functions that the mosque institutions have served for thousands of years [19].

Social welfare activities are one of the major sectors where mosques contribute throughout the world for Muslim and non-Muslim communities alike. Based on the virtue of Islam, mosques are recommended to take part in welfare activities and take care of the needy and the poor.

Another research conducted by Ahmad Ashraf discussed the relationship between the Mosque and the commercial center or bazaar and how each entity influences another in various issues. He said, the recent revolution and revolts within Iran's social and political history were centered on this bazaar-mosque alliance [20]. It is important to note how mosques can even play roles in altering the political powers of a region with their ability to accommodate revolutionary activities.

Erkoçu \& Buğdacı recommend a transparent and welcoming architecture for the mosque, which would help to increase its understanding and acceptance among Muslims and non-Muslims. This way, the building itself can acquire a central and significant position within the society, serving the community. Moreover, the transparency would give a clear understanding to the community member about what happened inside the mosque [21].

Tariq Ramadan, the famous Islamic scholar and thinker in our time, emphasized that a mosque must be simple and beautiful. He then highlighted the age-old tradition of services that mosques provided, such as education, food supply, and other vital necessities to the local community with little money. The mosque must be welcoming people so that they would be encouraged to come, eat, and discuss there. It should also teach people as what the expression suggests "No worship without knowledge" [21].

Multi-functionality and flexibility make mosques able to pay for themselves better. Multiple parties share the costs of maintenance and operation, and if one of them wants to move on, it's easy to make and do an adjustment. As a result, multi-functionality and flexibility make it easier for the building to stand the test of time [21] [22].

Types of spaces within and surround the mosque should also be taken into account. This space varies from context to context, and apart from the prohibited or sacred area of a mosque, other spaces should have flexible qualities to accommodate a range of functions in an effective way [5] [6].

Exploring the concept of mosque design, Erkoçu \& Buğdacı stepped into a whole new dimension for the mosque and said that there is a possibility of forming digital mosques, which anyone can visit on the internet. The only building involved would be one's room or home or even the mobile phone [21].

\section{DISCUSSION}

Based on the literature review, the analysis on the functional aspects of mosque illustrated a wide range of different activities incorporated with the institution of mosque for a long time. Scholars from 
different backgrounds and times pointed out the activities incorporated with a mosque from various perspectives. Some scholars emphasized the religious activities performed in the mosque, while others showed more enthusiasm for socio-cultural and socioeconomic activities.

Table 1. Recorded activities of a mosque by past researchers and scholars

\begin{tabular}{|c|c|c|c|c|c|c|}
\hline Prog. & $\begin{array}{c}\text { Educational } \\
\text { Program }\end{array}$ & Social Program & $\begin{array}{l}\text { Economic } \\
\text { Program }\end{array}$ & $\begin{array}{l}\text { Welfare } \\
\text { Program }\end{array}$ & $\begin{array}{l}\text { Judicial } \\
\text { Program }\end{array}$ & $\begin{array}{c}\text { Miscellaneous } \\
\text { Program }\end{array}$ \\
\hline $\begin{array}{l}\text { (Hamid, } \\
\text { 1973) }\end{array}$ & $\begin{array}{l}\text { Madrasa } \\
\text { Maktab } \\
\text { Library }\end{array}$ & $\begin{array}{l}\text { Dormitory } \\
\text { Clinic }\end{array}$ & $\begin{array}{l}\text { Market } \\
\text { Shops }\end{array}$ & & & $\begin{array}{l}\text { Recreational } \\
\text { facilities for } \\
\text { children }\end{array}$ \\
\hline $\begin{array}{l}\text { (Rasdi, 1998) } \\
\text { (Rasdi, 2010) }\end{array}$ & $\begin{array}{l}\text { Educational program } \\
\text { for children, youth, } \\
\text { men, women, and } \\
\text { elderlies }\end{array}$ & $\begin{array}{l}\text { Distribution of } \\
\text { Zakat } \\
\text { Fostering Islamic } \\
\text { brotherhood }\end{array}$ & & $\begin{array}{l}\text { Receive } \\
\text { and } \\
\text { distribute } \\
\text { charity } \\
\text { (sadaqa) }\end{array}$ & $\begin{array}{l}\text { Administrative } \\
\text { functions }\end{array}$ & \\
\hline $\begin{array}{l}\text { Ustaz Taib } \\
\text { Azamuddin } \\
\text { Mohamed } \\
\text { Taib } \\
\text { (reported by } \\
\text { (Rasdi, 1998) }\end{array}$ & & $\begin{array}{l}\text { Accommodation } \\
\text { for the travelers } \\
\text { Health clinic }\end{array}$ & $\begin{array}{l}\text { Sales space for } \\
\text { products and } \\
\text { items } \\
\text { Rentable rooms } \\
\text { for Muslims }\end{array}$ & $\begin{array}{l}\text { Public } \\
\text { welfare } \\
\text { offices }\end{array}$ & & $\begin{array}{l}\text { Recreational } \\
\text { facilities for } \\
\text { children and } \\
\text { adults }\end{array}$ \\
\hline $\begin{array}{l}\text { (Ferrarotti et } \\
\text { al., 1988) }\end{array}$ & & & $\begin{array}{l}\text { Bazaar- mosque } \\
\text { alliance }\end{array}$ & & & \\
\hline $\begin{array}{l}\text { (Hillenbrand, } \\
\text { 2004) }\end{array}$ & $\begin{array}{l}\text { Learning center } \\
\text { Center for } \\
\text { scholarship } \\
\text { Publication } \\
\text { Authorization of } \\
\text { academic works } \\
\text { Certification } \\
\text { Library } \\
\text { Lecture sessions } \\
\text { Debate and } \\
\text { discussion }\end{array}$ & $\begin{array}{l}\text { Accommodation } \\
\text { for the travelers } \\
\text { Hospitals } \\
\text { Marriage }\end{array}$ & $\begin{array}{l}\text { Book shops } \\
\text { Food facilities }\end{array}$ & $\begin{array}{l}\text { Morgues } \\
\text { Charity } \\
\text { distribution } \\
\text { Burial }\end{array}$ & $\begin{array}{l}\text { Divorce } \\
\text { Law courts }\end{array}$ & $\begin{array}{l}\text { Preservation } \\
\text { of relics } \\
\text { (museum) } \\
\text { Military bases }\end{array}$ \\
\hline $\begin{array}{l}\text { (Harun-ur- } \\
\text { Rashid, } \\
\text { 2004) }\end{array}$ & $\begin{array}{l}\text { Mosque-based } \\
\text { children education } \\
\text { program } \\
\text { Developing Islamic } \\
\text { Encyclopedia } \\
\text { Islamic publication } \\
\text { programs } \\
\text { Research } \\
\text { Imam training } \\
\text { centers } \\
\text { Mosque library }\end{array}$ & $\begin{array}{l}\text { Free health } \\
\text { facilities } \\
\text { Disaster } \\
\text { management } \\
\text { Zakat board }\end{array}$ & & $\begin{array}{l}\text { Social } \\
\text { welfare } \\
\text { Poverty } \\
\text { alleviation } \\
\text { Financial } \\
\text { donations }\end{array}$ & & $\begin{array}{l}\text { Da'wah } \\
\text { programs }\end{array}$ \\
\hline $\begin{array}{l}\text { (Omer, 2010) } \\
\text { (Omer, 2013) }\end{array}$ & $\begin{array}{l}\text { Learning center } \\
\text { Intellectual } \\
\text { discourse } \\
\text { Study circles }\end{array}$ & $\begin{array}{l}\text { Medical } \\
\text { treatment and } \\
\text { nursing }\end{array}$ & & $\begin{array}{l}\text { Charity } \\
\text { center } \\
\text { Detention } \\
\text { and } \\
\text { rehabilitati } \\
\text { on center }\end{array}$ & $\begin{array}{l}\text { The seat of } \\
\text { Prophet's } \\
\text { (PBUH) } \\
\text { government }\end{array}$ & $\begin{array}{l}\text { Leisure } \\
\text { activities } \\
\text { Provision for } \\
\text { women and } \\
\text { children }\end{array}$ \\
\hline
\end{tabular}




\begin{tabular}{lll}
\hline $\begin{array}{l}\text { (Erkoçu \& } \\
\text { Buğdacı, }\end{array}$ & $\begin{array}{l}\text { Multifunctional } \\
\text { spaces for gener- } \\
\text { ating income }\end{array}$ & $\begin{array}{l}\text { Digital portals } \\
\text { for mosques } \\
\text { Activities to } \\
\text { welcome non- } \\
\text { Muslim people }\end{array}$ \\
\hline $\begin{array}{l}\text { (Cheema et } \\
\text { al., 2014) }\end{array}$ & $\begin{array}{l}\text { Disaster manage- } \\
\text { ment programs }\end{array}$ & Relief pro- \\
\hline $\begin{array}{l}\text { (Hamdani et } \\
\text { al., 2021 }\end{array}$ & & grams \\
& & Intermediation \\
& & $\begin{array}{l}\text { and waiting } \\
\text { place for com- } \\
\text { munity }\end{array}$ \\
\hline
\end{tabular}

Table 1 presents the compilation of activities recorded by the scholars with an additional category to include any other activities that belong outside the scope of these types. As a mosque is primarily a religious institution, spiritual activities (i.e., prayer, recitations, etc.) are not included in the table.

\section{- Recommended activities for mosque institution}

Following the prior discussion on the functional aspects of a mosque from different viewpoints, this section proposed six major programs: educational, social, economic, welfare, judicial, and miscellaneous programs to establish the role of mosque institution from a functional perspective.

Figure 2 and 3 represents the compilation of all activities recorded from different sources categorized under six predefined sections comprising educational, social, economic, welfare, judicial and miscellaneous programs.

\section{- Educational and social activities}

These activities allow the community members to learn and discuss the religion and other relevant topics from the scholars and implement the knowledge to develop the Muslim community. Unfortunately, in contemporary societies, all people do not usually have the provision for attending institutions providing formal religious education except the Islamic school students, which is quite a few. So, in Muslim communities, it is recommended that the mosques arrange these kinds of programs regularly. From the study cases, it was recorded that most communities are willing to participate in these kinds of educational and social programs arranged by their local community mosques despite their busy and scheduled urban life.

\section{- Rational economic scheme: income generation and welfare}

For the financial sustenance of the mosque, effective economic schemes are recommended to be applied from the very beginning. Most of the mosques usually survive on donation. Because of this, these mosques can barely manage to carry their own expense for salaries and bills, let alone helping out the community's members. If this is the case, mosques cannot effectively participate in community development through social welfare. So, the management committee must make a plan for commercial activities along with the other programs. In Muslim communities, mosques have an advantage because the community members visit the mosque five times every day. Therefore, any commercial activity governed by the mosque will naturally have the support of these people to sustain.

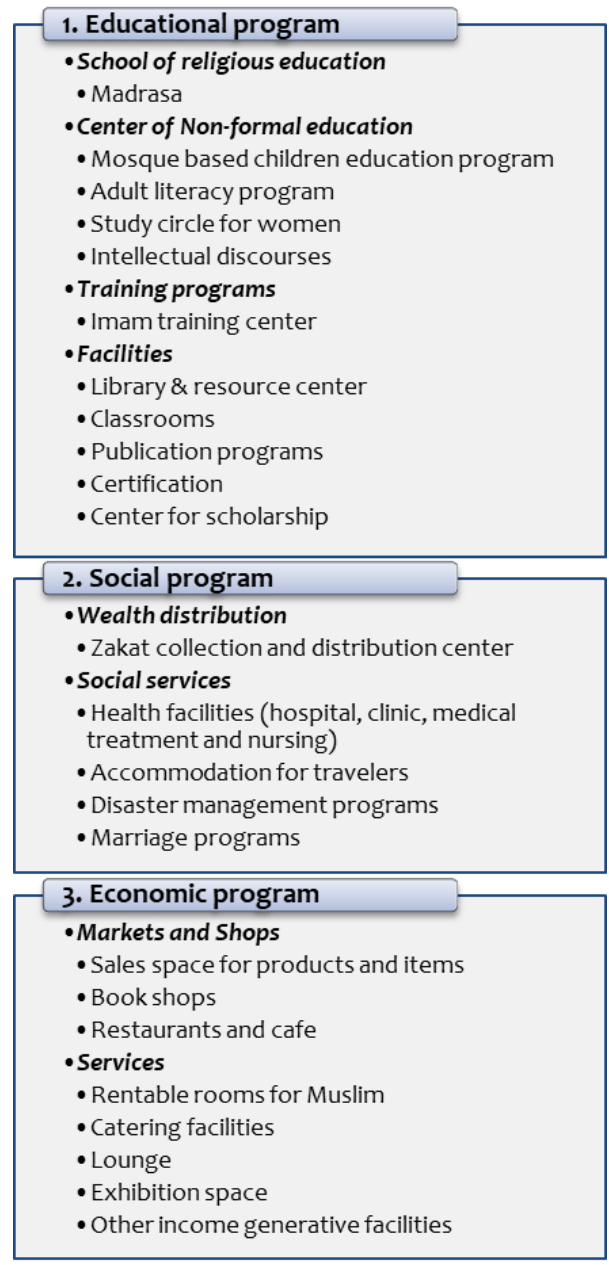

Figure 2. Functional aspects of the mosque institution

\section{- Fiqh and Islamic jurisprudence}

Modern-day mosques are not expected to perform judicial activities. However, members of Muslim communities tend to inquire about different Fiqh issues to maintain an Islamic lifestyle. The queries may vary from questions regarding issues of purification to issues such as marriage and divorce. Therefore, a mosque can be the ideal place for people to learn about the day to days Fiqh issues from local scholars. 


\begin{tabular}{|l|}
\hline 4. Welfare program \\
- Social welfare \\
- Rehabilitation center \\
- Orphanage \\
- Morgues and burial services \\
-Economic welfare \\
- Charity (sadaqa) distribution center \\
- Relief programs \\
- Poverty alleviation programs \\
- Financial donations \\
\hline 5. Judicial program \\
- Judicial services on religious issues \\
- Law (shariah) courts \\
- Divorce \\
- Center for judicial verdicts on new issues \\
(fatwaa) \\
\hline 6. Miscellaneous \\
- Recreational facilities \\
• Children playing zone \\
- Youth playing area \\
- Leisure activity facilities \\
- Parks \\
- Other facilities \\
- Museum \\
- Digital portals for mosques \\
- Activities to welcome non-Muslims \\
•Dawah programs \\
\hline
\end{tabular}

Figure 3. Functional aspects of mosque institution (contd.)

\section{- Provision of leisure activities}

The youth in any society is the key to bringing positive changes. They have the energy, time, and creativity to get involved with the issues of the community and take part in active developmental works. So the mosque must provide sufficient facilities for leisure and entertainment activities to attract the youth to its premises. Leisure activities are also useful for children and the elderly member of society. It ensures a healthy interaction among different age groups, thus creating harmony in society.

\section{CONCLUSION}

From the Islamic perspective, there are two aspects that shape the Muslim nation, i.e., the spiritual element guiding human relationship to its Creator and the relationship with a fellow human being (Habluminallah wa. Habluminannas). As developed by the early Muslim generation, the mosque institution was the most effective place where the Muslims could maintain a balance between the aspects mentioned earlier. The spiritual needs were fulfilled through individual and communal worship, while the relationship with fellow Muslims and non-Muslims were maintained through diversified communal activities. However, as discussed in this study, the contemporary mosques are devoid of most communal facilities that the early generation of mosques used to have. To address this issue, the mosque institution's function is studied in this paper from a historical perspective through the works of notable scholars in this field. 67 different activities were recorded for nine prominent scholars, and the activities were organized into 13 sub-categories. The sub-categories are placed under six major functional aspects of a mosque institution: educational, social, economic, welfare, judicial, and miscellaneous programs.

This comprehensive categorization of the mosque's function is expected to benefit the designers to assess the possibility of incorporating relevant functions into the mosque. It should be noted that the institution of the mosque varies in size according to the capacity requirement. A small mosque or a musollah might not have the same wholesome programs as a large mosque, such as the district or state. Nevertheless, the aim is to maximize the possibility of incorporating suitable functions depending on the mosque's size that can cater to the surrounding community and, as a result, aid the Muslims to realize the concept of Habluminannas. The mosque institutions all over the Muslim and nonMuslim world are expected to be able to portray the ideal image of a true community development center. In that case, the role of a mosque, as maintained by the early generation of Muslims with prophetic guidance, can once again make vital changes to the Muslim communities.

The institution of the mosque, throughout the ages, served as a communal facility to develop the Muslim society as a whole. The discussion above portrays how people were attached to this institution. Later, in the course of time, the Muslim community gradually lost the strength of its connection with the mosque. However, the modern time puts a quest in front of the Muslims to search for the appropriate framework for contemporary mosques so that, once again, the Muslim community can rejuvenate itself with its age-old tradition of developing the individual as well as social life by making their mosques more active and meaningful for every sphere of life. Unfortunately, the available literature also shows a gap in the study of mosque institutions and their contribution to community development.

The timelessness of mosque institutions demands that the reinterpretation of its activities and architecture to match modern Muslim societies' needs is utterly significant. As stated by Spahic Omer, "the mosque institution is bound to serve as a focal point of the religious and social life of the Muslims, advancing its physical stature as a guidepost and its message as an inspiration and guidance in all of our development, building, and planning undertakings" [6].

"It is not for the polytheists to maintain the mosques of Allah (while) witnessing against themselves with disbelief. (For) those, their deeds have become worthless, and in the Fire, they will abide eternally. The mosques of Allah are only to be maintained by those who believe in Allah and the Last Day and establish prayer and give zakah and do not fear except Allah, for it is expected that those will be of the (rightly) guided" [Surah At-Tawba: 17-18] [23]. 


\section{REFERENCES}

[1] A. Hamid, "The role of the mosque in Muslim settlements: A study of the mosque as a planning element in South Asian Muslim Countries," Columbia University, 1973.

[2] S. Omer, "Some Lessons from Prophet Muhammad ( SAW ) in Architecture: The Prophet's Mosque in MadÊnah," pp. 115-140, 2010.

[3] Z. Desai, Mosques of India, First. Delhi: Ministry of Information and Broadcasting. Government of India, Delhi, 1966.

[4] Z. W. Nasir, "Phenomenological Case Study of Spiritual Connectedness in the Academic Workplace," Int. J. Acad. Res. Bus. Soc. Sci., vol. 9, no. 9, Sep. 2019, doi: 10.6007/IJARBSS/v9i $9 / 6410$.

[5] M. T. H. M. Rasdi, The mosque as a community development centre: Programme and architectural design guidelines for contemporary muslim societies. UK: Penerbit UTM, 1998.

[6] S. Omer, "Studies in the Islamic Built Environment," IIUM Press, 2013. http:// iiumpress.iium.edu.my/bookshop/

wwwgooglecom-18 (accessed Nov. 11, 2014).

[7] J. Pedersen, H. Affes, M. Frishman, H.-U. Khan, and R. Joseph, "Masjid," in Encyclopedia of Islam and the Muslim World, First prin., R. C. Martin, Ed. 2003, p. 437.

[8] R. Hillenbrand, Islamic Architecture: Form, Function, and Meaning. Columbia University Press, 2004

[9] M. T. H. M. Rasdi, Rethinking Islamic Architecture. Strategic Information and Research Development Centre, 2010.

[10] H. Al-Awadi, "Four great imams," 2008, [Online]. Available: http:// www.awakening.org/heshamalawadi/.

[11] H. Othman, M. Yazid, M. Yunos, and N. A Ismail, "Issues and Problems of Modern Mosques Design in Malaysia: A Critical Analysis," Adv. Environ. Biol., vol. 9, no. April, pp. 330-337, 2015.

[12] S. Peshkova, "Bringing the mosque home and talking politics: Women, domestic space, and the state in the Ferghana Valley (Uzbekistan)," Contemp. Islam, vol. 3, pp. 251-273, 2009.

[13] Z. Nawaz, Me and the Mosque. Canada: Reel Diversity, 2005.

[14] M. Dabbagh Niya, N. Utaberta, and S. Maulan, "Significance of the Application of Universal Design in Mosque Buildings in Malaysia," Appl. Mech. Mater., vol. 747, pp. 72-75, 2015, doi: 10.4028/www.scientific.net/AMM.747.72.

[15] A.-H. Z. A.-A. Al-Mundhiri, Sahih Muslim, ArabicEn. Riyadh, KSA: Darussalam, 2000.

[16] A. H. Tamuri, M. F. Ismail, and K. A. Jasmi, "A New Approach in Islamic Education: Mosque Based Teaching and Learning," J. Islam. Arab. Educ., vol. 4, no. 1, 2012.

[17] O. Lanre, A. Malik, and A. S. Hamad, "THE IMPACT OF MOSQUE IN DEVELOPMENT OF ISLAMIC EDUCATION IN NIGERIA ( IMDIEN )," GSE E-JOURNAL Educ., vol. 2, pp. 93-98, 2014

[18] A. R. Cheema, R. Scheyvens, B. Glavovic, and M. Imran, "Unnoticed but important: revealing the hidden contribution of community-based religious institution of the mosque in disasters," Nat. Hazards, vol. 71, pp. 2207-2229, 2014, doi: 10.1007/s11069-013-1008-0.

[19] C. Candland, "Faith as social capital: Religion and community development in southern asia," Policy Sci., vol. 33, no. 3-4, pp. 355-374, 2001, doi: $10.1023 / \mathrm{A}: 1004857811117$.

[20] F. Ferrarotti, M. Kashef, H. Modarresitabatabai, V. Nowshirvani, A. Rassam, and C. Tilly, "Bazaar-Mosque Alliance: The Social Basis of Revolts and Revolutions," vol. 1, no. 4, pp. 538-567, 1988.

[21] E. Erkoçu and C. Buğdacı, The Mosque. Political, Architectural and Social Transformations Ergün Erkoçu, Cihan Buğdacı |. Belgium: NAi Uitgevers, 2009.

[22] A. M. Hamdani, A. Suprapti, and R. S. Rukayah, "Open space function in plaza area in Central Java Great Mosque," IOP Conf. Ser. Earth Environ. Sci., vol. 623, p. 012094, Jan. 2021, doi: 10.1088/1755-1315/623/1/012094.

[23] Sahih International, The Qur'an English Meanings. Jeddah: Data, King Fahd National Library Cataloging-in-Publication, 2004. 